though firm to the touch were easily cut into, presenting on section a very vascular surface but no hæmorrhage. The tortuous, red, fungouslike appearance of those portions of the plexus choroides which did not actually compose the tumour was most marked, and a great contrast to the firm and somewhat pale ncoplasm.

The tumours were embedded in paraffin, cut, and subsequently treated with chloroform.

Under the microscope the tumour was scen to be composed of pre-existent and newly-formed blood-vessels held in a basis-tissue composed largely of young connective tissue. The blood-vessels were full of blood and more or less dilated in a sacculated and spherical manner, and being tortuous formed wide abrupt cavities more or less separated by the young connective tissue noted. The wall of the smaller vessels was composed of an cndothelial layer, and external to that a single layer of cubical epithelioid cells (see Plate IV.). In the firmer or older portions of the neoplasms the tissue-basis was plentiful and wellformed, and held the blood-vessels wide apart, whilst in the younger parts it was of much more recent formation and not nearly so plentiful. In the latter position, i.e., in the more recently formed portions, the blood-vessels, new and old alike, were margined by clusters of leucocytes, and it was to be noted that in these groups there was a marked tendency to the formation of embryonic blood-vessels-the cells were arranged in parallel rows-and even in this stage of their growth the vast majority of the new vessels contained blood. In the plexus choroides adjoining the tumours this formation of new bloodvessels was the marked feature, especially where no young connective tissue had been formed. The farther removed from the free plexus choroides that the neoplasm was examined the greater was the proliferation of the connective-tissue elements; and the thicker and stronger became the walls of the new vessels and the greater their calibre. The walls of the blood-vessels, old or new, did not appear to be implicated in any retrogressive change, such as calcareous deposit, nor was there any thickening of the coats of pre-existent vessels to be noted.

From the above it may fairly be inferred that the development of this angioma was from new granulation tissue, if one may so term the leucocytic exudation noted on the surface of the plexus choroides; new vessels and vascular sinuses having first been formed in that exudate there followed development and gradual condensation of connective tissue between the vessels, until the stage of tumour was reached. The neoplasms were not produced merely by dilatation and cavernous degeneration of blood-vessels.

\title{
A FCETAL MONSTROSITY*
}

By F. L. Gooch, F.R.C.V.S., Stamford.

ON the 27 th of November last I was called to attend to what proved to be a very peculiar and difficult case of calving. On examination I found that the hinder end of the calf was presenting, the hind fetlocks appearing outside the vulva. I was able to deliver the hind quarters as far as the pelvis, but no farther, nor could I make a satisfactory 


\section{FEtTAL MONSTROSITY (Mr Gooch's Case).}

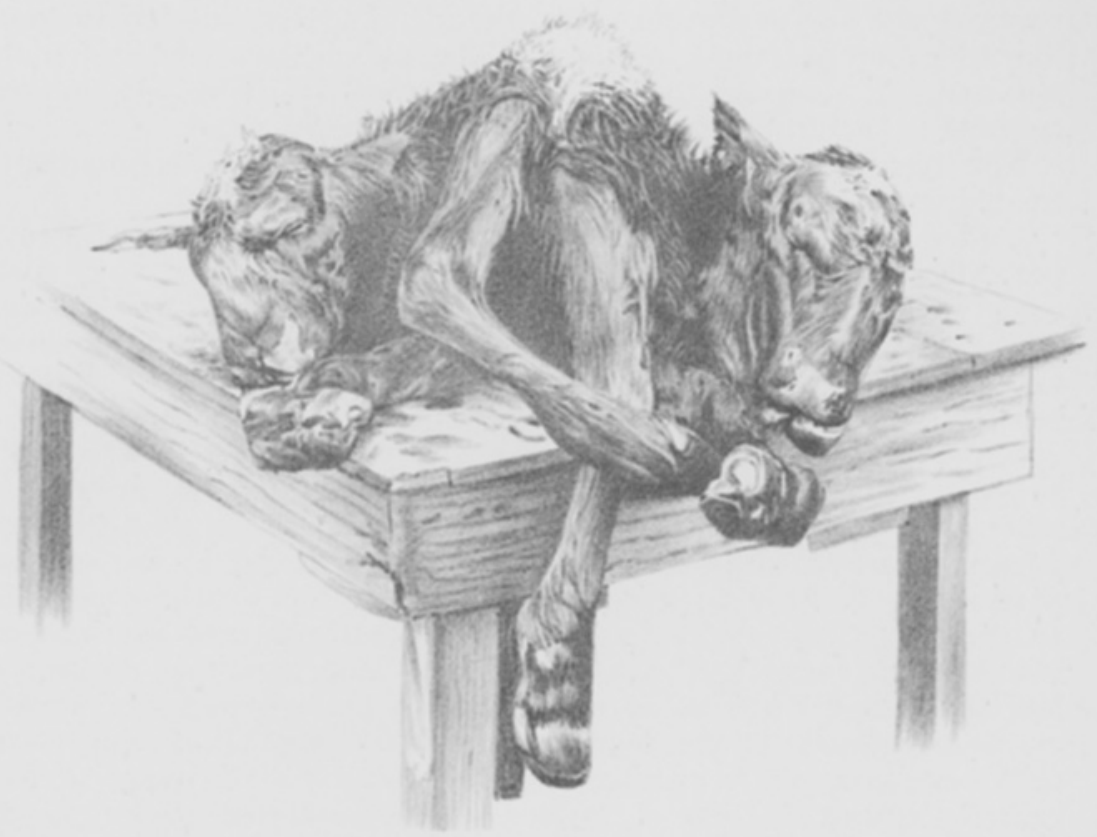

ANGIOMA.-PLEXUS CHOROIDES.

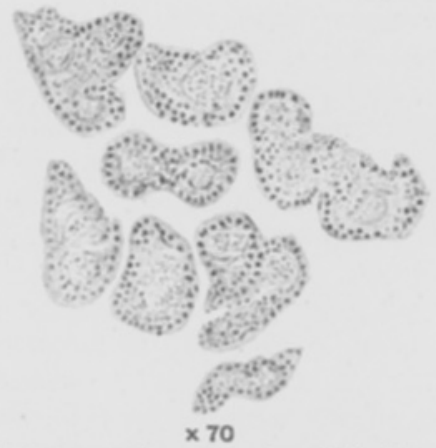

Transverse section of several small blood-vessels in early stage of formation, and showing cellular sheath and wall.
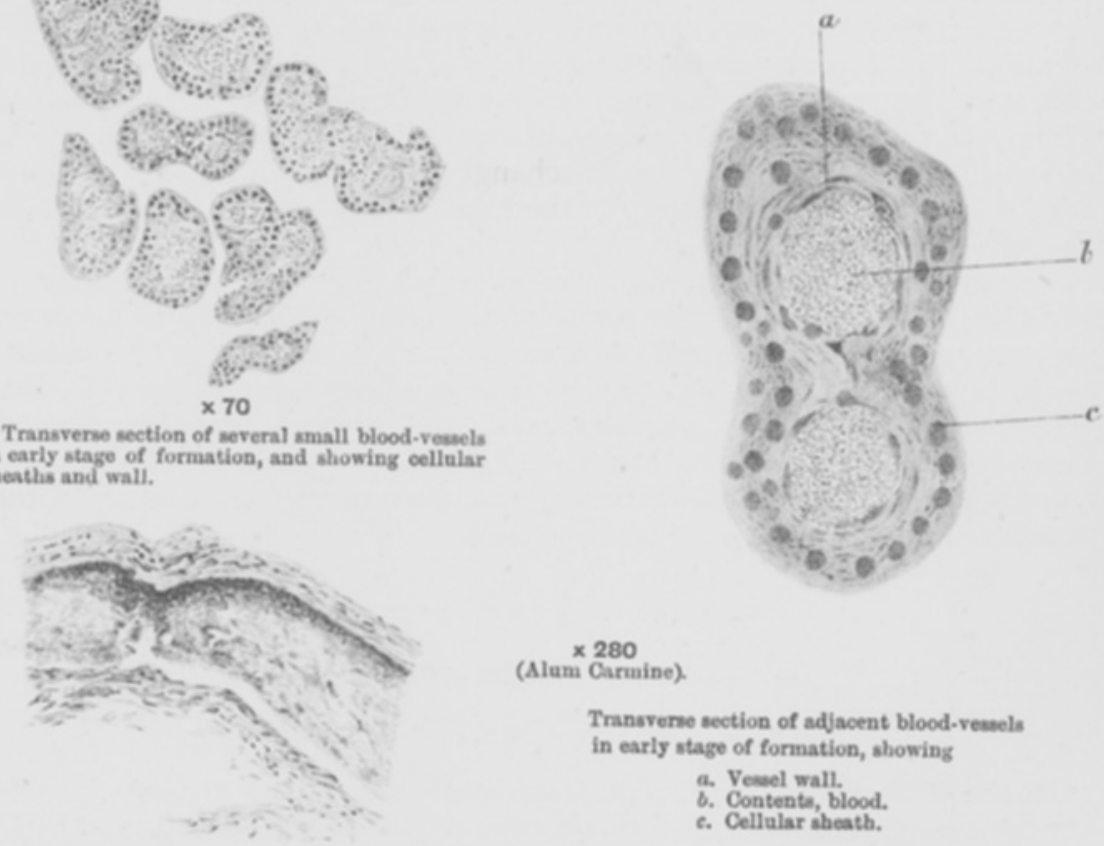

$\times 70$

Portion of a more organised vessel much dilated, and ahowing veseel wall with the contents, but no cellinlar sheath.

\section{(Alum Carmine)}

Transverse section of adjacent blood-veasels in early stage of formation, showing
a. Veseel wall.
6. Contents, blood.
c. Cellular sheath. 
exploration in order to discover the obstruction. I therefore dissected the skin back, and amputated the hind extremities at the hip joints. I then discovered the nature of the foetus and gave up all hope of being able to effect delivery without sacrificing the heifer. When the latter was killed I extracted the calf, a photograph of which is reproduced in Plate IV. It was fully developed, and it had given signs of being alive until some time after labour had commenced. It had two well-developed heads and spines, a third rudimentary spine (three tails), four fore-legs, and two hind-legs.

\section{A CASE OF OPEN JOINT SUCCESSFULLY TREATED.}

By Joseph Abson, F.R.C.V.S., Sheffield.

UPON reading the article by Professor $F$. Smith in your September number, on "Some Joint Diseases of the Horse," I am constrained to record a case that $I$ attended in the months of July and August last, and which, I think, may be of interest to your readers.

The subject, a three-years-old Hackney filly, was left standing at a door attached to a two-wheeled vehicle, and without any one in charge, with the result that she bolted and ultimately came to grief by overturning the trap and smashing it up, but at the time it was supposed that she had escaped injury herself. She was taken home and straightway turned out into a meadow adjoining the house of the owner. On the following morning the mare was noticed to be lame on the off hind leg. She was brought home, and the limb was well washed, and it was then noticed that she had a small wound on the hock. I was sent for, and on examination discovered a perfectly round opening into the true hock joint, quite the size of a threepenny piece. This was as clearly defined as though cut by a saddler's punch, was on the inner aspect, well to the front of the joint, and nearly at the bottom of the capsule. The white glistening articular cartilage of the astragalus was plainly visible, even at a distance of several feet away, and any movement of the joint could readily be seen.

Little synovia appeared to have escaped, from what I could learn, and the lameness for such a serious lesion was only trifling. My prognosis was most unfavourable. The mare was put into a loose box where she was least likely to be disturbed, her head tied up to prevent lying down, and orders were given to on no account move her-iodoform pure to be dusted over the part 3 times a day.

On the following morning I set out to see my patient, armed with slings, but to my utter astonishment she was very little worse than on the previous day. I also found she was very "tickle" from the accident, and decided not to attempt to sling her, at all events for the present. She was accordingly simply left tied up, and remained so for a little over 3 weeks, during which time the wound was continually dressed with the iodoform. The opening gradually closed, the discharge - which at no time had been excessive, and which throughout kept its typical character of synovia-ceased, and lameness disappeared. Some slight enlargement of the bones on the 